The Common Agricultural Policy of the European Union the present and the future

EU Member States

point of view 



\section{INSTITUTE OF AGRICULTURAL AND FOOD ECONOMICS NATIONAL RESEARCH INSTITUTE}

\section{The Common Agricultural Policy of the European Union - the present and the future}

\section{EU Member States point of view}

Editors:

dr Marek Wigier

prof. dr hab. Andrzej Kowalski

Proceedings of the International Scientific Conference

"The Common Agricultural Policy of the European Union - the present and the future" Multi-Annual Programme 2015-2019

"The Polish and the EU agricultures 2020+. Challenges, chances, threats, proposals" 5-7 December 2017 Stare Jabłonki, Poland

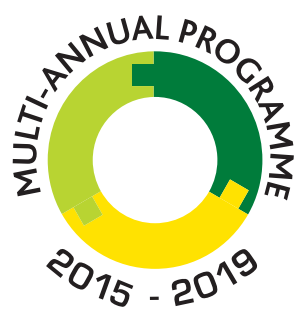

THE POLISH AND THE EU AGRICULTURES 2020+ CHALLENGES, CHANCES, THREATS, PROPOSALS

Warsaw 2018 
This monograph was prepared under the Multi-Annual Programme 2015-2019

"The Polish and the EU agricultures 2020+. Challenges, chances, threats, proposals".

The publication is a collection of selected papers delivered at the 22th edition of the International Scientific Conference organized by the Institute of Agricultural and Food Economics - National Research Institute. The theme of the conference was "The Common Agricultural Policy of the European Union the present and the future. The conference was placed on 5-7 December 2017 in Stary Jabłonki in Poland. Common Agricultural Policy was and still is one of the key pillars of European integration. Published in two volumes materials refer directly to the current and future of the CAP in EU and non EU member states, the strategic objectives and principles of agricultural policy for the agri-food sector and rural areas, address the issues of equilibrium between agriculture, forestry and land use, relate to the dilemmas for the EU budget and the CAP after 2020, CAP instruments and their adjustment, transformations of the rural economy and programming of the rural and agricultural policy, as well as productivity and production efficiency and tensions between sectoral action and between different models of territorial activities.

In the Scientific Committee of the Conference was participated: Prof. Andrzej Kowalski (IAFE-NRI, Poland), Prof. Drago Cvijanonivić (University of Kragujevac, Serbia), Prof. Thomas Doucha (IAEI, Czech Republic), Noureddin Driouech, PhD (CIHEAM, Italy), Prof. Szczepan Figiel (IAFE-NRI, Poland), Prof. Masahiko Gemma (Waseda University, Japan), Prof. Wojciech Józwiak (IAFE-NRI, Poland), Prof. Jacek Kulawik (IAFE-NRI, Poland), Prof. Yuriy Oleksiyovych Lupenko (IAE, Ukraina), Prof. Věra Majerová (CULS, Prague), Prof. Dimitre Nikolov (IAE, Bulgaria), Maire Nurmet, PhD (EMÜ, Estonia), Prof. Gabriel Popescu (ASE, Romania), Norbert Potori, PhD (AKI, Hungary), Prof. Włodzimierz Rembisz (IAFE-NRI, Poland), Piotr Szajner, PhD (IAFE-NRI, Poland), Prof. Alina Sikorska (IAFE-NRI, Poland), Prof. Jonel Subić (IAE, Serbia), Prof. Samuele Trestini (UNIPD, Italy), Prof. Olga Varchenko (Bila Tserkva National Agrarian University, Ukraine), Dipl.-Ing. Klaus Wagner (AWI, Austria), Marek Wigier, PhD (IAFE-NRI, Poland), Prof. Józef St. Zegar (IAFE-NRI, Poland)

In the Organising Committee of the Conference was participated: Małgorzata Bułkowska (IAFE-NRI, Poland), Anna Hankiewicz (IAFE-NRI, Poland), Joanna Jaroszewska (IAFE-NRI, Poland), Joanna Korczak (IAFE-NRI, Poland), Krzysztof Kossakowski (IAFE-NRI, Poland), Irena Mikiewicz (IAFE-NRI, Poland), Małgorzata Mikołajczyk (IAFE-NRI, Poland), Lech Parzuchowski (IAFE-NRI, Poland), Ewa Sierakowska (IAFE-NRI, Poland), Paulina Smakosz (IAFE-NRI, Poland), Leszek Ślipski (IAFE-NRI, Poland), Marek Wigier, PhD (IAFE-NRI, Poland).

Reviewers:

Professor Dimitre Nikolov, Institute of Agricultural Economics, Sofia, Bulgaria

Professor Gabriel Popescu, The Bucharest University of Economic Studies, Bucharest, Romania

Professor Samuele Trestini, University of Padva, Italy

Proofreader

Katarzyna Mikulska

Technical editors:

Joanna Jaroszewska, Barbara Pawtowska, Ewa Sierakowska, Kamila Tomaszewska,

Barbara Walkiewicz

Translated by

Summa Linguae S.A.

Cover Project

Leszek Ślipski

ISBN 978-83-7658-743-1

DOI: $10.30858 / \mathrm{pw} / 9788376587431$

Instytut Ekonomiki Rolnictwa i Gospodarki Żywnościowej

- Państwowy Instytut Badawczy

ul. Świętokrzyska 20, 00-002 Warszawa

tel.: (22) 5054444

faks: (22) 5054636

e-mail:dw@ierigz.waw.pl

http://www.ierigz.waw.pl 


\section{Contents}

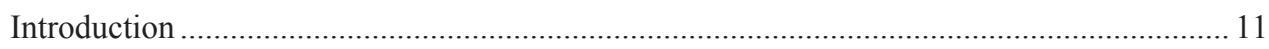

Dr Marek Wigier

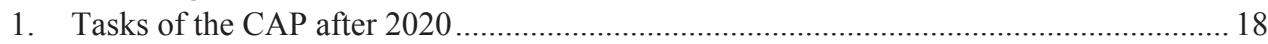

Dr hab. Julian Krzyżanowski

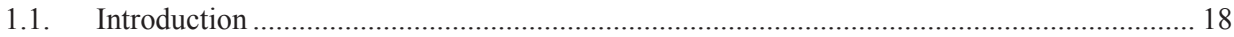

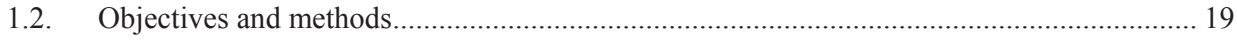

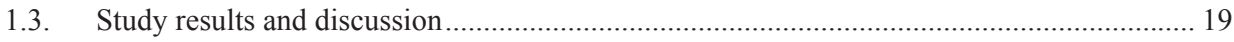

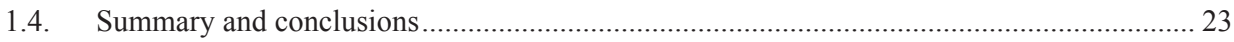

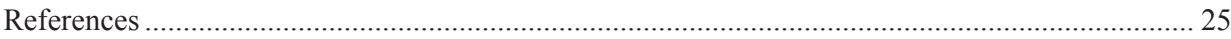

2. An assessment of the regional impacts of post-2020 CAP budgetary cuts on production

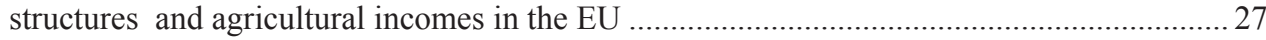

PhD Norbert Potori, PhD János Sávoly, PhD Szabolcs Biró

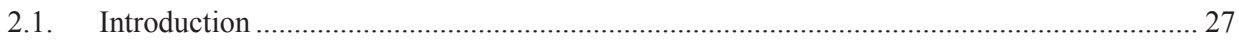

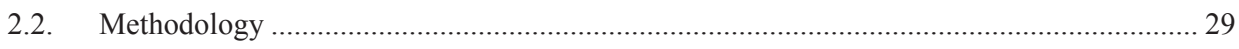

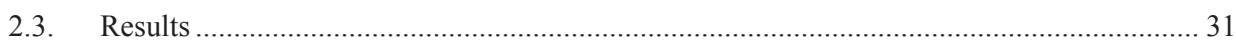

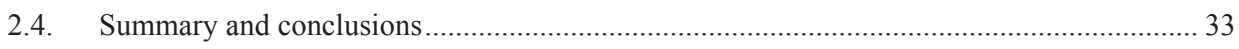

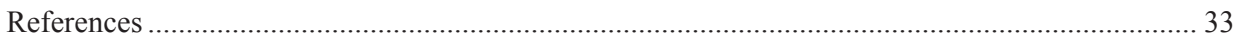

3. Is there room for financial instruments in the Common Agricultural Policy? Casus of

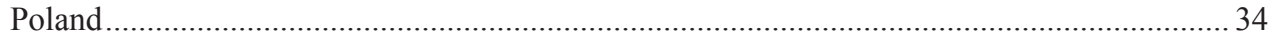

Prof. dr hab. Jacek Kulawik, PhD Barbara Wieliczko, PhD Michat Soliwoda

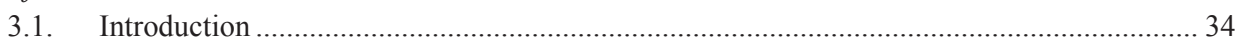

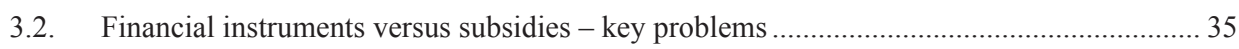

3.3. The use of financial instruments under the EU policy ......................................................... 37

3.4. Example of the use of FI in the 2014-2020 programming period ......................................... 38

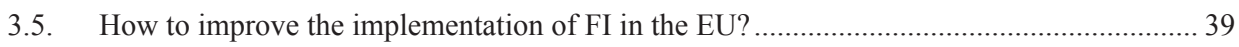

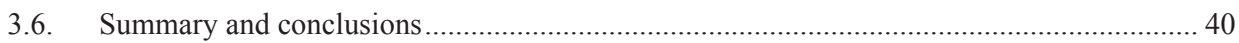

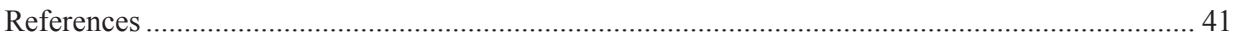

4. The past, present and future of the CAP - the Hungarian viewpoint ............................. 43

Dr Tamás Mizik

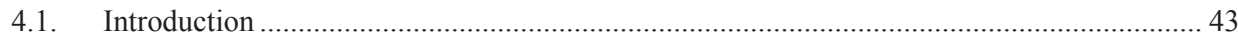

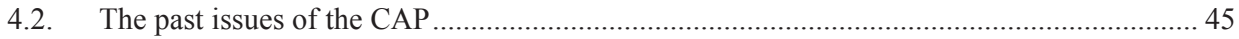

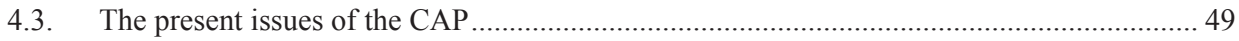

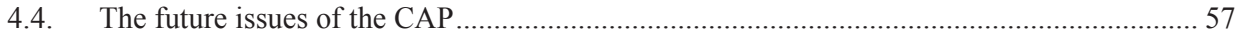

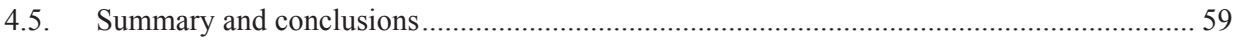

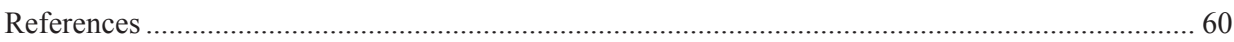


5. Going beyond the Rural Development Programme: a Master Plan for Austria's rural areas in the framework of the CAP

Dip.-Ing. Klaus Wagner

5.1. Introduction

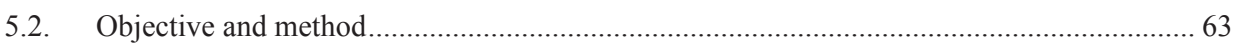

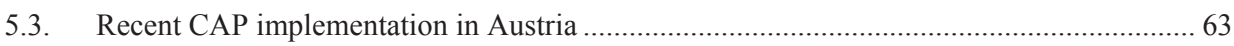

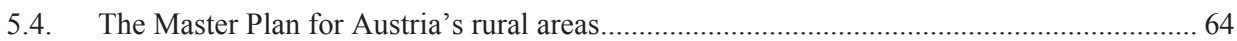

5.5. CAP in the system of the EU policy objectives and in the view of regional science

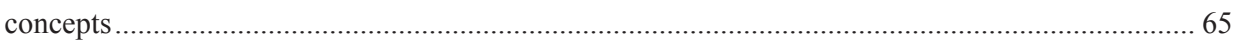

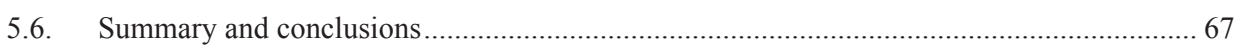

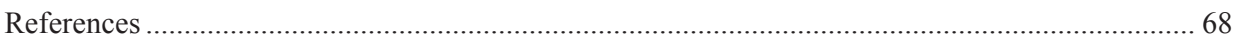

6. Possibilities to connect the Romanian agricultural research to the market requirements 69 Prof. Gabriel Popescu

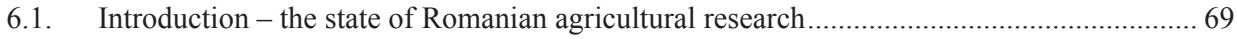

6.2. The problems faced by agricultural research since 1990 ..................................................... 71

6.3. Possible solutions for the recovery of Romanian agricultural research ................................ 76

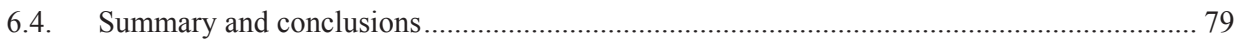

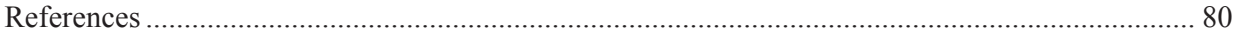

7. Price relationships of the production factors as exogenous determinants of production in agriculture.

Prof. dr hab. Włodzimierz Rembisz, PhD Adam Waszkowski

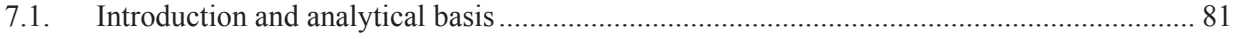

7.2. Relationships of prices of the capital, labour and land factors - hypothetical approach...... 83

7.3. Relationships of prices of the capital, labour and land factors - empirical approach .......... 84

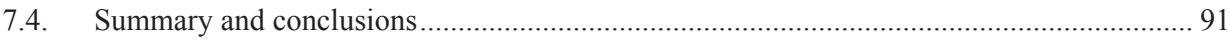

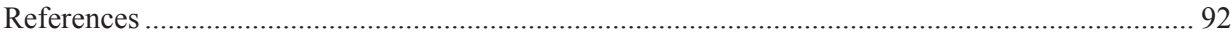

8. Effects of direct payments on agricultural development in Bulgaria ............................. 93 PhD Bozhidar Ivanov

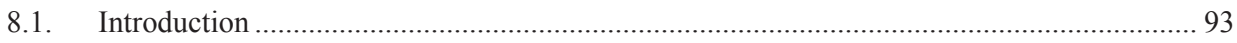

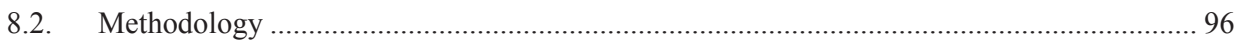

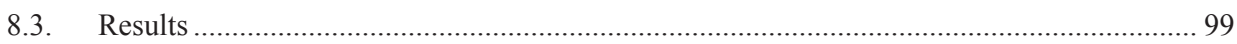

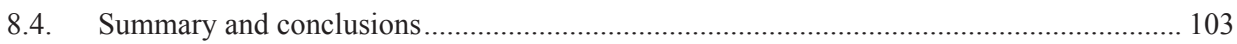

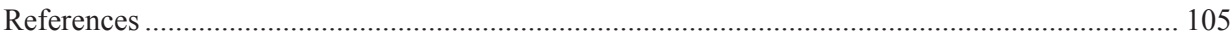

9. Re-adjusting risk management within the CAP: evidences on the implementation of the

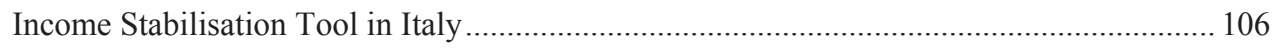
Prof. Samuele Trestini, PhD Elisa Giampietri

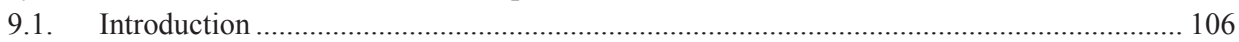

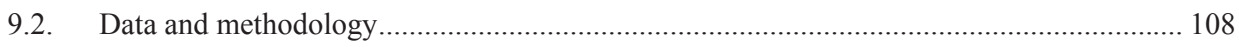




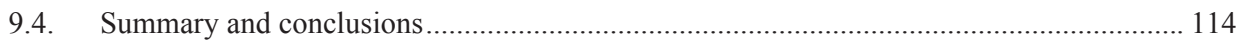

References

10. Comparison of risk management tools under the CAP of the EU, the US Farm Bill

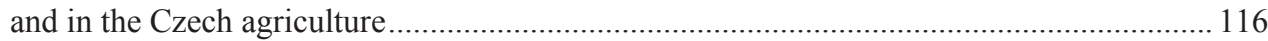
Ing. Václav Vilhelm, CSc., Ing. Sumudu Namali Gouri Boyinová, PhD Jindřich Špička

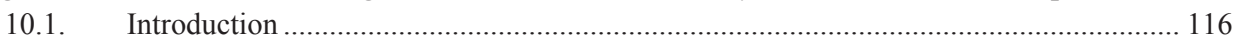

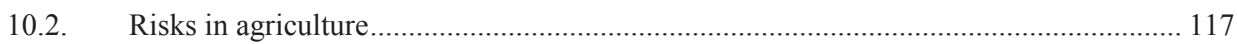

10.3. Risk management policy in the United States Farm Bill 2014 _..................................... 118

10.4. Risk management policy of the European Union's CAP ................................................ 119

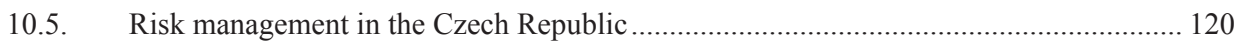

10.6. Comparative analysis of risk management policies ........................................................ 121

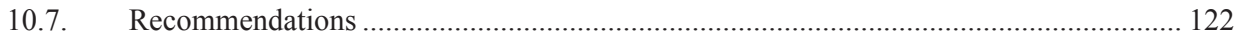

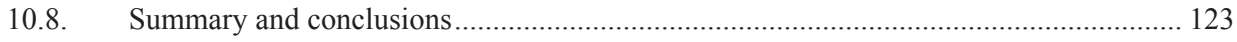

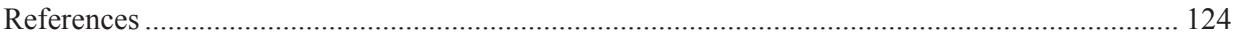

11. Factors determining the crop insurance level in Poland taking into account the level

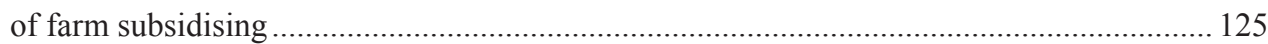

Prof. Adam Was, PhD Pawet Kobus

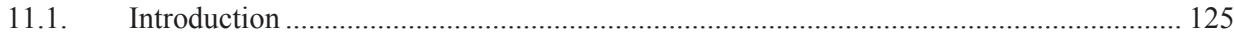

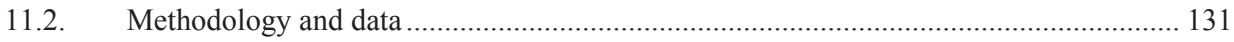

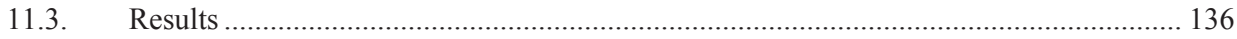

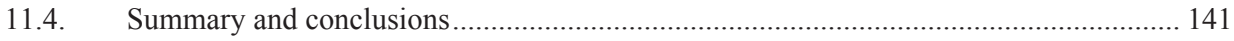

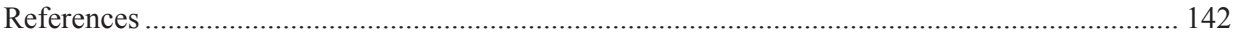

12. Farms and agricultural enterprises for development of sustainable and smart cooperatives: a multifactor approach using digital farm management ............................... 147 Prof. dr habil Adriana Mihnea, Prof. dr Dimitre Nikolov, dr Krasimir Kostenarov

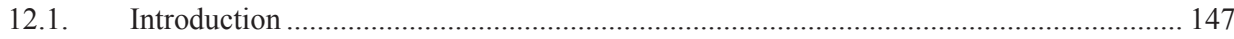

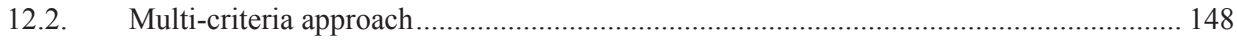

12.3. Construction of Farm Management Model ................................................................ 150

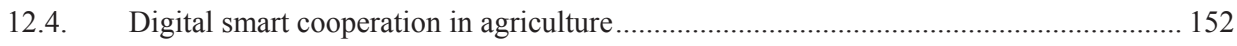

12.5. Application of the ANP Farm Management Model ....................................................... 154

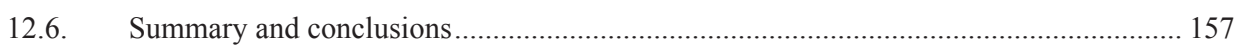

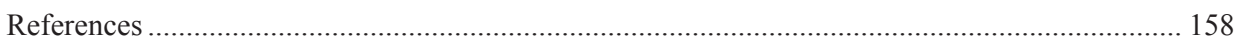

13. Brexit - potential implications for the Polish food sector .............................................. 159

Dr Katarzyna Kosior, Dr Łukasz Ambroziak

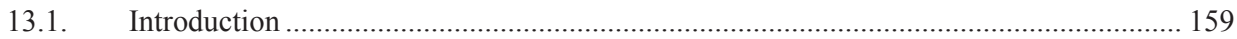

13.2. Negotiations on Brexit - what should be the model of the future relations? ..................... 161

13.3. The future of the EU finances and the CAP in the context of Brexit .............................. 163 
13.4. Impact of possible changes in the CAP budget on the net balance of Poland and transfers to the Polish agriculture.

13.5. The potential impact of Brexit on agri-food trade between Poland and the United

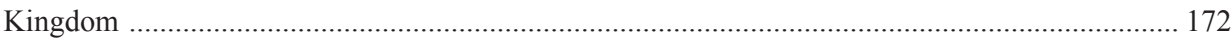

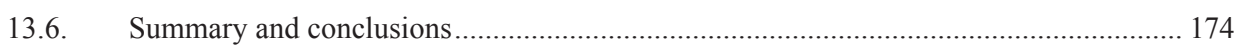

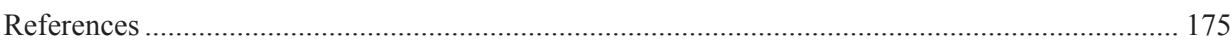

14. The Transatlantic Trade and Investment Partnership (TTIP): a threat or an opportunity for the EU-Mediterranean agriculture and agri-food sector? An exploratory survey ........... 177 Dipl.-Ing. Katja Pietrzyck, PhD Noureddin Driouech, Prof. Brigitte Petersen

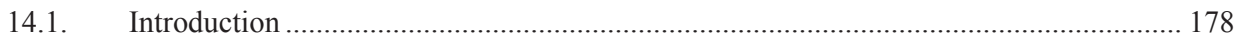

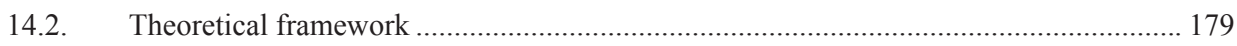

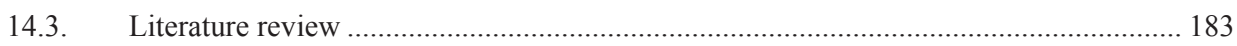

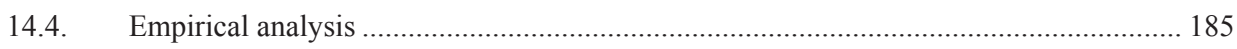

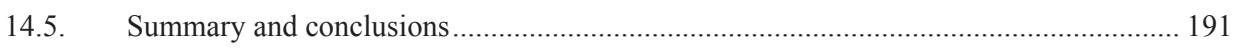

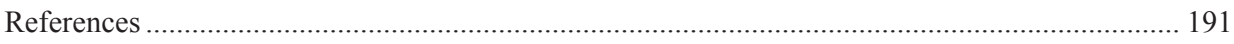

Appendix I: Overview of trade statistics regarding selected products ........................................... 195

15. The concept of short supply chains in the food economy............................................. 196

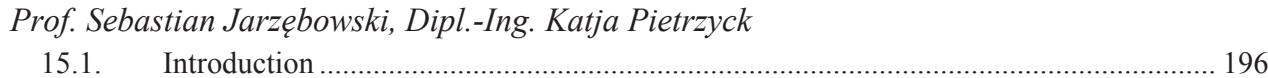

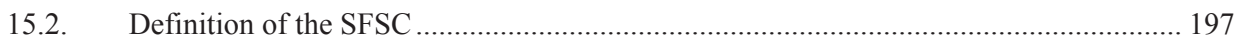

15.3. Development of short supply chains in Europe............................................................. 201

15.4. Global context of European short supply chains ........................................................... 205

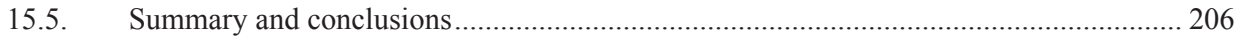

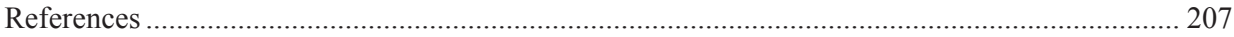

16. The CAP implementation in Wallonia - today performance and questions for the future -

A brief supplementary comment from Warmia and Mazury perspective............................. 209

PhD Philippe Burny, PhD Benon Gazinski

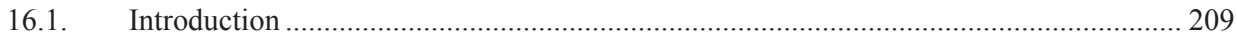

16.2. Implementation of the green payment in Wallonia in 2015 ........................................ 210

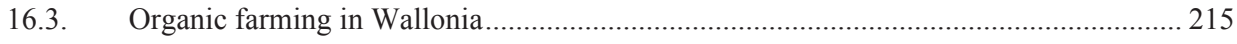

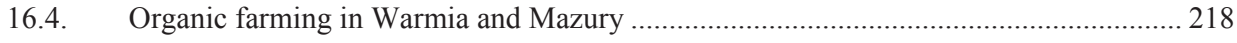

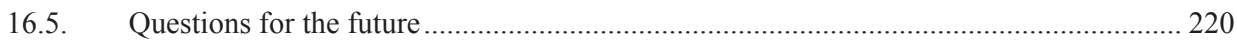

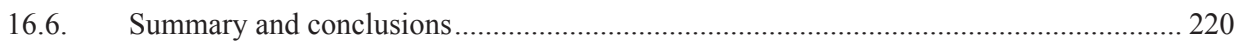

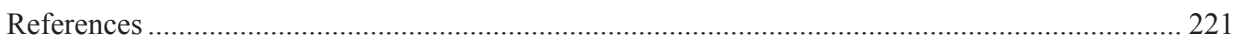

17. Afforestation of agricultural land financed from the RDP 2014-2020 ....................... 224

PhD Marek Zieliński

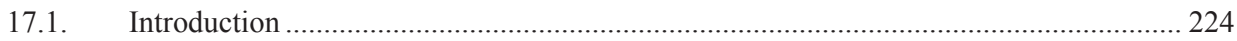

17.2. Natural farming conditions in Poland in regional terms................................................. 225 
17.3. The impact of natural farming conditions in Poland on the economic situation and the possibility of afforestation on farms

17.4. Land afforestation financed from the RDP 2014-2020 in regional terms

17.5. Importance of land afforestations financed under the RDP 2014-2020 in the EU climate policy for 2021-2030.

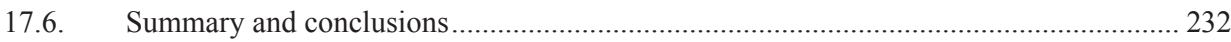

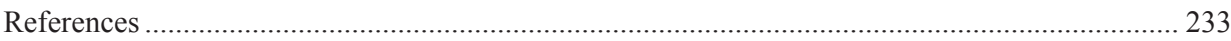

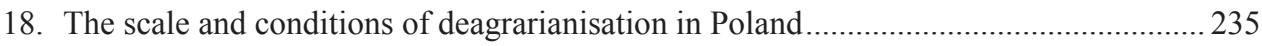

PhD Michat Dudek, PhD Bożena Karwat-Woźniak

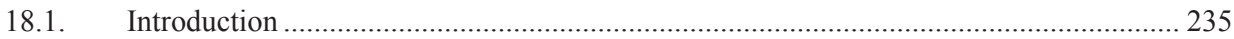

18.2. The conditions of the decrease in employment in agriculture ......................................... 236

18.3. The change in the scale of employment in agriculture in Poland and its conditions....... 238

18.4. The instruments of the Cohesion Policy and agriculture and rural development of the EU

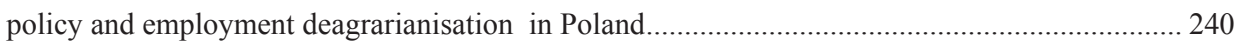

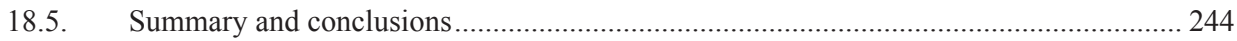

References 245

19. Socio-economic and environmental parameters and results of rural development under the CAP: the case of Bulgaria ................................................................................................ 247 Prof.dr.hab. Julia Doitchinova, Prof.dr.hab. Ivan Kanchev, Ass.Prof. Ralitsa Terziyska PhD, Ass.Prof. Kristina Todorova PhD

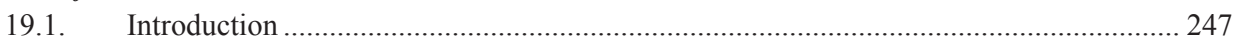

19.2. Changes in Bulgarian rural areas - socio-economic and environmental aspects................ 248

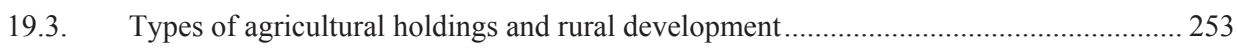

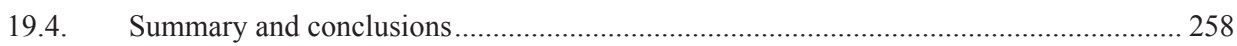

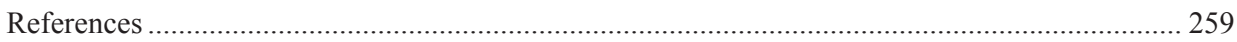

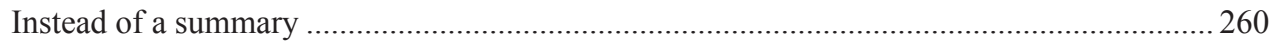

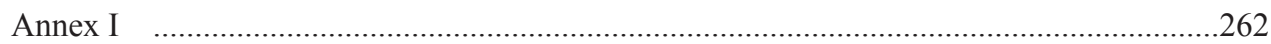




\title{
19. Socio-economic and environmental parameters and results of rural development under the CAP: the case of Bulgaria
}

\author{
Prof.dr.hab. Julia Doitchinova, Prof.dr.hab. Ivan Kanchev, \\ Ass.Prof. Ralitsa Terziyska PhD, Ass.Prof. Kristina Todorova PhD \\ University of National and World Economy, Sofia \\ juliadoj@abv.bg,kanchevsi@abv.bg,christalina22@gmail.com
}

DOI: $10.30858 / \mathrm{pw} / 9788376587431.19$

\begin{abstract}
During the ten years of our country's membership in the EU, the implementation of the Rural Development Programme have become a driving force for raising income and improving living conditions in the rural areas.

The purpose of this report is to assess the impact of the CAP on rural development after Bulgaria's accession to the EU. For this purpose an analysis and evaluation of the state and changes of the socio-economic, and environmental results, and parameters of the rural areas was performed for 2007-2016. The report's thesis is that rural development depends on the type of farming, its organization and the prerequisites for diversification of the rural economy. Demonstration will use statistical data on demographic, economic and environmental indicators on the rural areas.
\end{abstract}

Keywords: production agriculture, northern and southern types of agriculture, rural areas

JEL codes: Q15, Q16

\subsection{Introduction}

The models of agriculture have always had an impact on rural development. The production models which have been implemented over the last decades have led to an increase in production through an "intensive, industrially driven and expansionist agriculture with state support based primary on output and increased productivity" [Lowe et al.,1993, p. 221]. At the same time, some authors rightly emphasize that "the industrial agriculture, driving people out of farming and rural areas, contributed to a decrease or, in many cases, decline, of the economic and socio-cultural viability of rural areas" [Zegar, 2012, p. 25]. As a result of those transformation processes today's rural areas have to face multiple socio-ecological problems and crises. 
The structural change leads to modified working conditions and property situations in rural areas, with negative effects on small-scale farming, whose farmers are often forced to give up agricultural production [Feindt, 2008]. Placed in the context of diverse natural-climatic conditions, agricultural traditions and socio-economic conditions and structural changes are a prerequisite for various impacts and results for local development that are the subject of analysis by various researchers. Reviewing their findings and conclusions it can be summarized that at the end of the twentieth century the European Commission highlighted the existence of two types of European agriculture - the South and the North - with different characteristics, opportunities, problems and development barriers [EC, 1997].

Diversity studies are active mostly in Southern European countries where both models exist. Some authors [Fabiani and Scarano, 1995] analyse the dualism of the structure of agriculture - in Italy through the prism of differences backward versus productive holdings in Greece by comparing modern and traditional farming and drawing conclusions on the need for a transition to hybrid structures [Beopoulos and Damianakos, 1997; Beopoulos, 2003]. Analysing differences between northern and southern agriculture, researchers focus primarily on physical and economic indicators, and emphasize that the "relative balance of permanent/annual crops also shows notable differences in productive orientation of farms in the two groups of countries" [Arnalte-Alegre and Ortiz-Miranda, 2013, p. 42].

The purpose of the paper is to assess the impact of the CAP on rural development after Bulgaria's accession to the EU. For this purpose an analysis and evaluation of the state and changes of the socio-economic, and environmental results, and parameters of the rural areas is performed for the period of 2007-2016.

The report's thesis is that rural development depends on the type of farming, its organization and the prerequisites for diversification of the rural economy. Demonstration will use statistical data on demographic, economic and environmental indicators on the rural areas.

\subsection{Changes in Bulgarian rural areas - socio-economic and environmental aspects}

In Bulgaria, $88 \%$ of the municipalities are classified as rural areas (LAU 1), which are spread across $81 \%$ of the country's territory.

The population of these areas was $39 \%$ of the total count in 2007 and $27 \%$ in 2016. Overall, in the years of Bulgaria's membership in the EU, there has been a population decline of more than $8 \%$, worsening its age structure and average life expectancy. The total number of people living in Bulgaria was 7679 million in 2006 and by 2016 this number has changed to 7102 million. Life expectancy has also gone down to 70.4 years -71.2 for males and 78.2 for females. 
Figure 1 shows that there was growth in the last two age groups. The most significant is the increase in the relative share of people over 65 - by more than 3.4 points. This group reaches $20.7 \%$, while children and young people under 15 are only $14.1 \%$.

These negative processes are accompanied by an increase in income by more than $47 \%$, as the most significant increase is in pensions (54.6\%). Apart from the fact that many projects were implemented to stimulate entrepreneurial activity, the income from ownership and self-employment is preserved and remains low.

Figure 1. Age structure of the population (2006 and 2016)

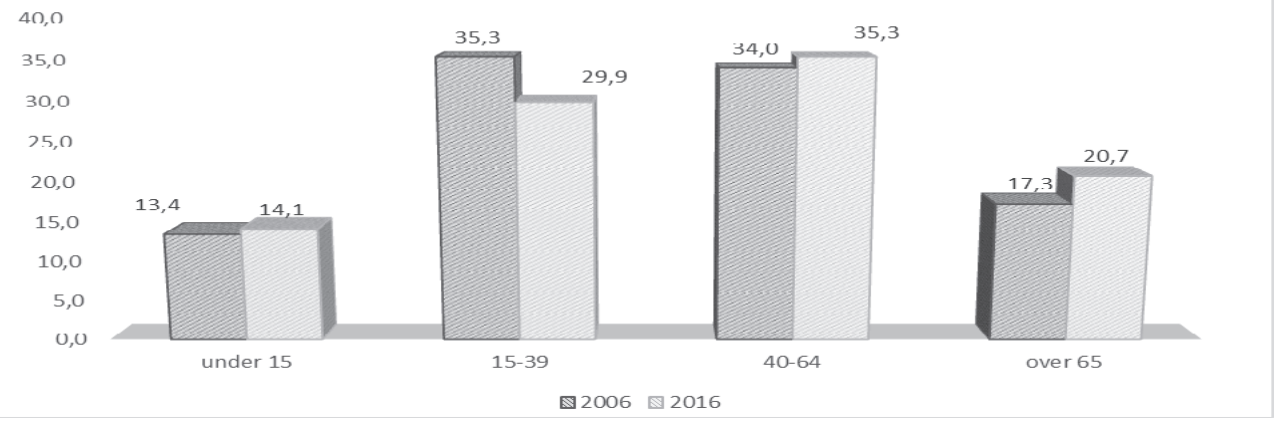

Source: own study based on NSI data for population.

Figure 2 shows that unemployment declines mainly in urban areas, while in some rural areas' it remains high and it is even rising. The processes of income growth and population decrease are the result of the ongoing restructuring of the Bulgarian economy and the localization of some sectors only in the big cities.

Broken down by regions, Figure 2 shows that unemployment in urban areas drops in all regions, while for rural areas in 2 of the regions it is rising - up to $20 \%$ in Northwest and $8 \%$ in South Central. It is quite interesting, that in the Southeast region the unemployment rates remain the same both for urban and rural areas.

These results show that despite the implementation of the RDP, which supported more than 25000 farms (Table 1), the unfavourable trends in rural development continue.

Positive change is observed in transport and social infrastructure in rural areas. The implementation of Bulgaria's first RDP improved the quality of life for rural residents. The implemented projects in the field of transport structure and urban development resulted in more than 2 thousand kilometers of new and renovated roads and more than 0.4 thousand km of streets; more than 2.5 thousand $\mathrm{km}$ are water systems. The social infrastructure, especially the local cultural centers, sports facilities and social services, was also significantly improved. 
Figure 2. Unemployment in the towns and villages of Bulgaria (\%)

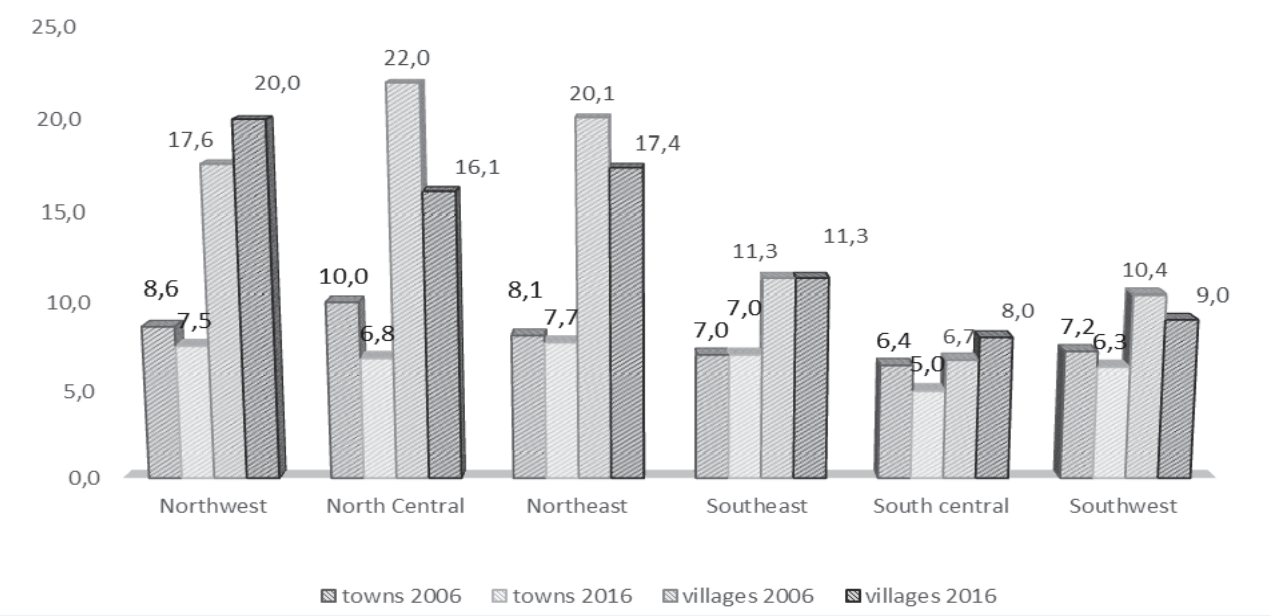

Source: National Statistical Institute, Unemployed and unemployment rates.

Table 1. Agricultural holdings within implemented projects under measures of the Rural Development Programme (2007-2013)

\begin{tabular}{|c|c|}
\hline Measures & Number or agricultural holdings \\
\hline $\begin{array}{c}\text { Modernization of farms } \\
\text { (M 121) }\end{array}$ & $\begin{array}{c}4552 \text { farms, investments worth over EUR 1 billion and finan- } \\
\text { cial assistance worth over EUR 515 million }\end{array}$ \\
\hline $\begin{array}{c}\text { Support for semi-market } \\
\text { holdings (M 141) }\end{array}$ & 7696 semi-market holdings \\
\hline $\begin{array}{c}\text { Setting up of young farmers } \\
\text { (M 112) }\end{array}$ & 5678 young farmers \\
\hline $\begin{array}{c}\text { Compensatory payments } \\
\text { more than 7000 farms - payments for environmentally friendly } \\
\text { and climate friendly activities as well as organic production }\end{array}$ \\
\hline
\end{tabular}

Source: $M Z F F$.

The environmental parameters of the rural development in Bulgaria can be traced out by examining the implementation of the agri-environmental scheme for 2007-2013. On the other hand, analyzing some of the basic agri-environmental indicators, which integrate environmental concerns into the Common Agricultural Policy in the EU, it is necessary to draw a conclusion about the state of the environmental aspects such as soil, atmosphere and water.

\section{Agri-environmental scheme}

As seen in Figure 3, the uptake of organic farming is continuously increasing from 2008 and 2013, with a more noticeable increase in 2012 and 2013. During 2008, there were only 306 of submitted applications and in 2013 there were 2129 , which is almost seven times higher. The number of biological opera- 
tors applying under Measure 214 for Agroecology and climate 2007-2013 is steadily rising and in 2012 it reaches 1250, which is 4 times higher than in 2008. In 2012 the certified areas are 11974 hectares (43\% growth compared to 2007) and the areas in transition to organic farming in 2012 are 27164 ha (growth over 5 times compared to 2007). In 2012, the main certified areas by type of plantation are as follows - permanent crops are about $26 \%$, meadows and pastures about $19 \%$ and arable crops $-53 \%$.

Figure 3. Number of submitted applications for agri-environmental measures in 2007-2013

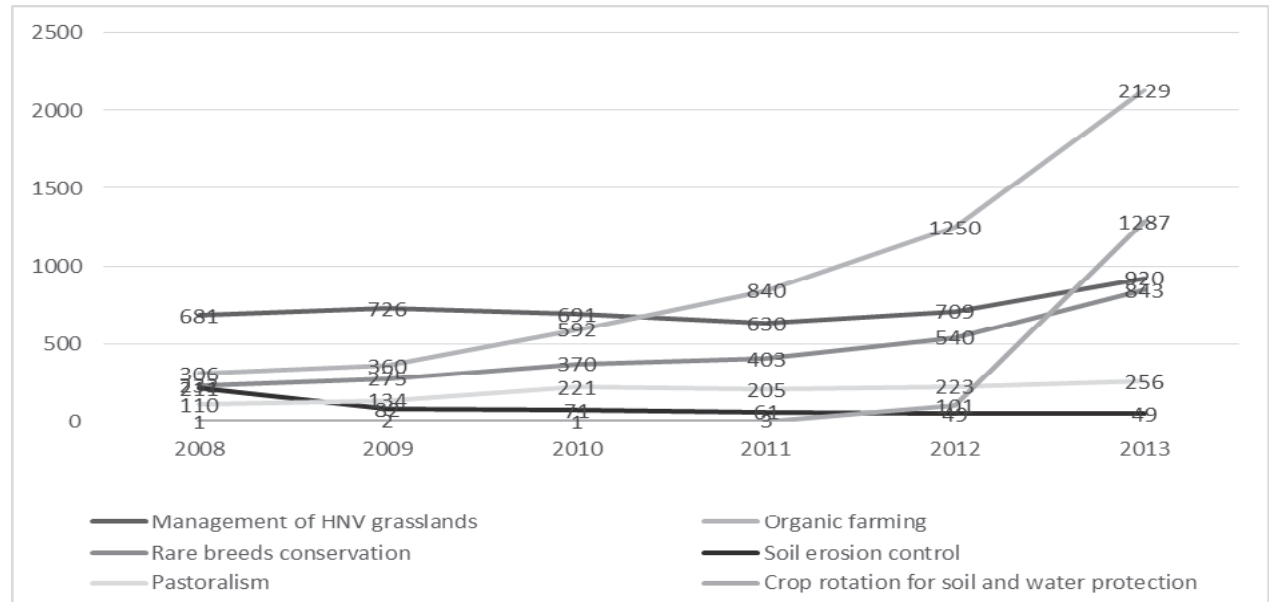

Source: Lessons learned, Assessment of the Rural Development Programme 2014-2020.

The measures for rare breeds' conservation and management of highnature valued grasslands, as well as pastoralism note almost a constant growth, as the first two have grown during 2012 and 2013. In comparison, the measure for soil erosion starts with high level in 2008 and since than it constantly decreases. The most noticeable change is in the crop rotation measure. In 2011, the uptake was close to zero, rising to 101 in 2012, and then sharply reaching 1287 applications in 2013.

The overall tendency is for significant increase in the areas where environmentally and climate friendly activities are carried out, as the uptake of agri-environmental measures has risen up to five times from 2008 to 2013.

\section{Environmental indicators}

Analysing some of the basic environmental indicators give us an insight into the effect which agricultural activity has on the environment.

The gross nutrient balance represents the total potential threat to the environment of nitrogen and phosphorous surplus or deficit in agricultural soils. 
A lack of both nutrients can cause degradation in soil fertility and erosion, while an excess may cause surface and groundwater pollution and eutrophication. Therefore nitrogen and phosphorous balance surpluses are being monitored in order to follow the requirements under the Water Framework Directive and the Nitrates Directive. For this purpose several sources of pollution have been examined, including the consumption of fertilizers, livestock population, crop production and areas of various types of crops.

The nitrogen balance added to an agricultural system and nitrogen removed from the system per hectare of agricultural land is regulated via the process of adding the nitrogen with mineral fertilizers and animal manure as well as nitrogen fixation mainly by legumes and deposition from the air. Comparing to 2007, in 2014 there is a slight increase in the nitrogen surplus from 24 to $28 \mathrm{~kg} / \mathrm{ha}$ (Figure 4).

Figure 4. Gross nutrient balance on agricultural land in Bulgaria and Poland
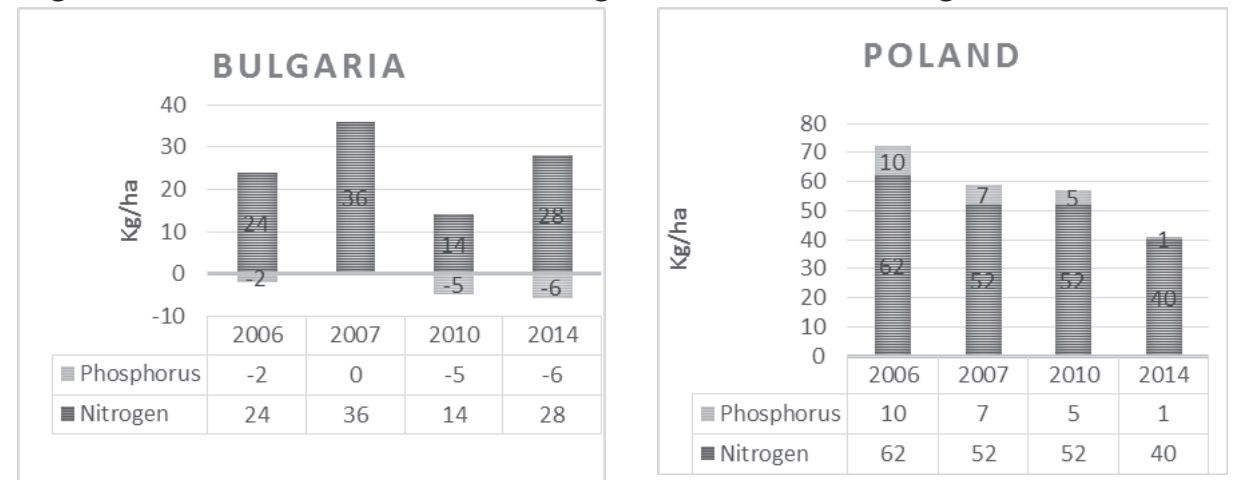

Source: own study based on Eurostat data.

This may be at some part due to the fact that in Bulgaria between 2007 and 2014 there has been a rise of about $80 \%$ in the consumption of inorganic fertilizers, including nitrogen. For the same period the decrease in the EU (28) is $12 \%$. For comparison the nitrogen balance in Poland has decreased from 62 to $40 \mathrm{~kg} / \mathrm{ha}$ for the same period.

A lack of phosphorous appeared in 2014 compared to 2006 when this balance was $-2 \mathrm{~kg} / \mathrm{ha}$, despite the fact that for the same period the consumption of phosphorous as fertilizer has almost doubled. In comparison, there is a slight decrease in the balance for the Union from $4 \mathrm{~kg} / \mathrm{ha}$ to $2 \mathrm{~kg} / \mathrm{ha}$, which shows a positive tendency between the input and output of this inorganic fertilizer. As for the data in Poland, the phosphorous balance reached $1 \mathrm{~kg} / \mathrm{ha}$ in 2014 .

Next indicator is the total utilized agricultural area (UAA) occupied by organic farming (existing organically farmed areas and areas in the process of conversion). For 2007-2016, the share of organic farming in Bulgaria has grown 
from $0.3 \%$ to $3.2 \%$ (Figure 5). This positive outcome has followed the bigger uptake of submitted applications for the organic farming measure under the Measure 214 Agri-environment payments.

Figure 5. Share of total utilized agricultural area under organic farming in Bulgaria and Poland

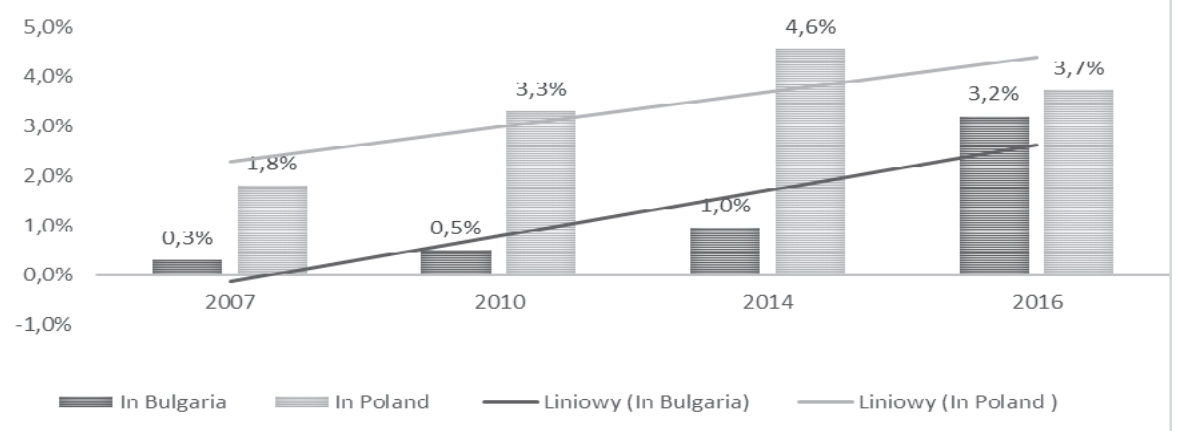

Source: own study based on Eurostat data.

It can be concluded, that there is a positive effect from the agrienvironmental measures on some of the environmental aspects. This is the most visible and traceable aspect regarding the organic farming, which increased from $0.3 \%$ of the UAA to $3.2 \%$.

For 2007-2013 there is a significant growth in the adoption of agrienvironmental measures. One of the most important ones - soil erosion measure - does not share this trend.

\subsection{Types of agricultural holdings and rural development}

Despite the relatively small territory, both types of agricultural models are present in Bulgaria - the northern and southern one. The first model developed successfully in the years of transition and membership of the country in the EU, becoming dominant in some rural areas of northern Bulgaria. It is based on the three main processes of modernization - "intensification (through mechanization, use of chemicals and variety selection), specialization (farmers concentrate on few products with higher returns) and concentration (production comes from fewer farms and specific regions)" [Ilbery and Maye, 2010]. Applied mainly on farmed agricultural land in agricultural holdings specializing in the production of arable crops, it has led to a high efficiency of production and labor productivity based on the modernization of applied technologies. 
In the southern regions of the country, the number of family-type farms, combining the production of vegetables and fruits with different livestock, predominate in the number and distribution. They are mainly used in family labour, as mechanized part of the work processes. Some of the key features of the two farming models are shown in Table 2.

Table 2. Key features of farming models

\begin{tabular}{|l|l|l|}
\hline \multicolumn{1}{|c|}{ Type of agriculture } & \multicolumn{1}{|c|}{ Northern agriculture } & \multicolumn{1}{c|}{ Southern agriculture } \\
\hline Specialization & $\begin{array}{l}\text { Narrowly specialized in cere- } \\
\text { al and technical crops }\end{array}$ & $\begin{array}{l}\text { Various productions - livestock hus- } \\
\text { bandry, vegetable specialization, } \\
\text { permanent crops }\end{array}$ \\
\hline Applied technologies & Highly mechanized & $\begin{array}{l}\text { More limited use of mechanization } \\
\text { (for part of the work processes) }\end{array}$ \\
\hline $\begin{array}{l}\text { Utilized agricultural } \\
\text { areas }\end{array}$ & $\begin{array}{l}\text { Large areas of utilized agri- } \\
\text { cultural area }\end{array}$ & $\begin{array}{l}\text { Smaller areas of used agricultural } \\
\text { land }\end{array}$ \\
\hline $\begin{array}{l}\text { Predominant type of } \\
\text { agricultural holdings }\end{array}$ & $\begin{array}{l}\text { Sole traders, LTD } \\
\text { company }\end{array}$ & Family farms \\
\hline Used labour & Mostly hired & Mostly family labour \\
\hline $\begin{array}{l}\text { Capital input per unit } \\
\text { area }\end{array}$ & Large & Relatively limited \\
\hline
\end{tabular}

Source: own study.

To compare the implications of applying two models of agriculture in Bulgaria, two planning regions (NUTS2 level) are selected - Northwest and South Central (Figure 6). The Northwest region is concentrated on the production of cereals and some crops grown on large areas. The most numerous are farms cultivating arable crops.

Agriculture in the South Central region is specialized in the production of field vegetables, fruit and grapes. Livestock is well developed. This specialization is also a reason for the differing characteristics of the farms with regard to the average sizes, the combination of crops, the factors of production used and others.

In the Northwestern region, most agricultural land is used by commercial companies (45.64\%) and farms of natural persons (26.20\%), while in the South Central - by farms of natural persons $(49.9 \%)$ and commercial companies $29.34 \%$ (Figure 7).

Essential (more than 4.4 times) are the differences in the average size of a farm. In the Northwest, the average size of utilized agricultural area per holding is 28.5 ha versus 6.47 ha in South Central. In the holdings of individuals, these differences are 7.78 ha (Northwest) versus 3.28 ha (South Central); in cooperatives -885.6 ha (Northwest) versus 394.1 ha (South Central), and in companies - 583.4 ha (Northwest) versus 179.5 ha (South Central). 
Figure 6. Planning Regions in Bulgaria

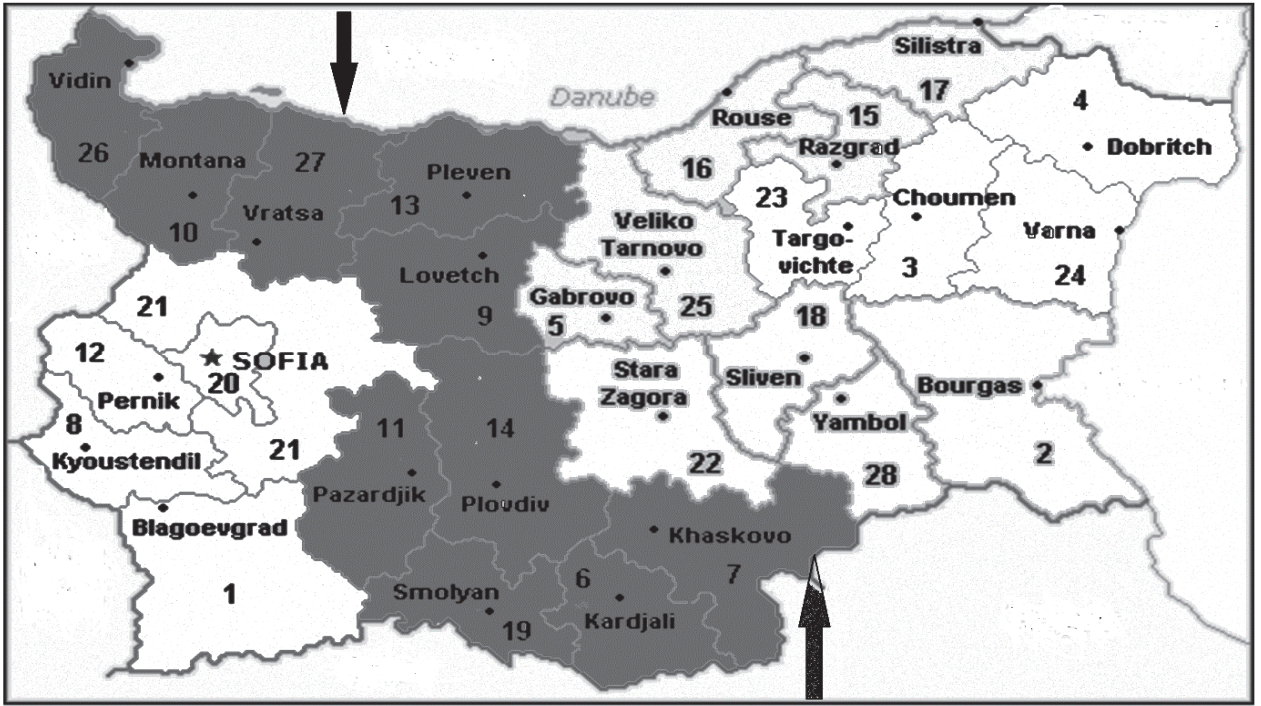

Source: own study.

Despite the high relative share of agricultural land leased before Bulgariaąs EU membership, the importance of renting continues to increase. In the Northwest area, the relative share of agricultural land used in lease agreements is higher.

Figure 7. Allocation of used agricultural land according to the legal status of holdings (\%)

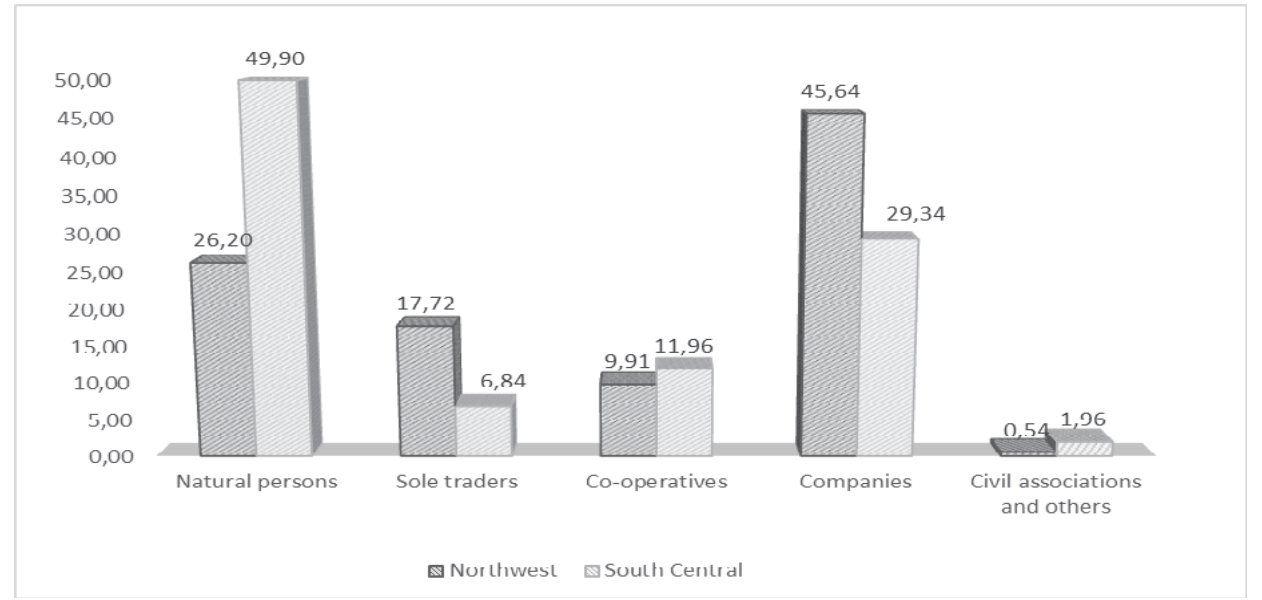

Source: MZFF, Department "Agrostatistic”. 
For 2013, the relative share of rented land reached $84.78 \%$, while in South Central it was $74.4 \%$ (Figure 8 ), which represents an increase of $6 \%$ and $7.25 \%$, respectively.

Figure 8 . The relative share of rented land in the Northwest and South Central regions $(\%)$

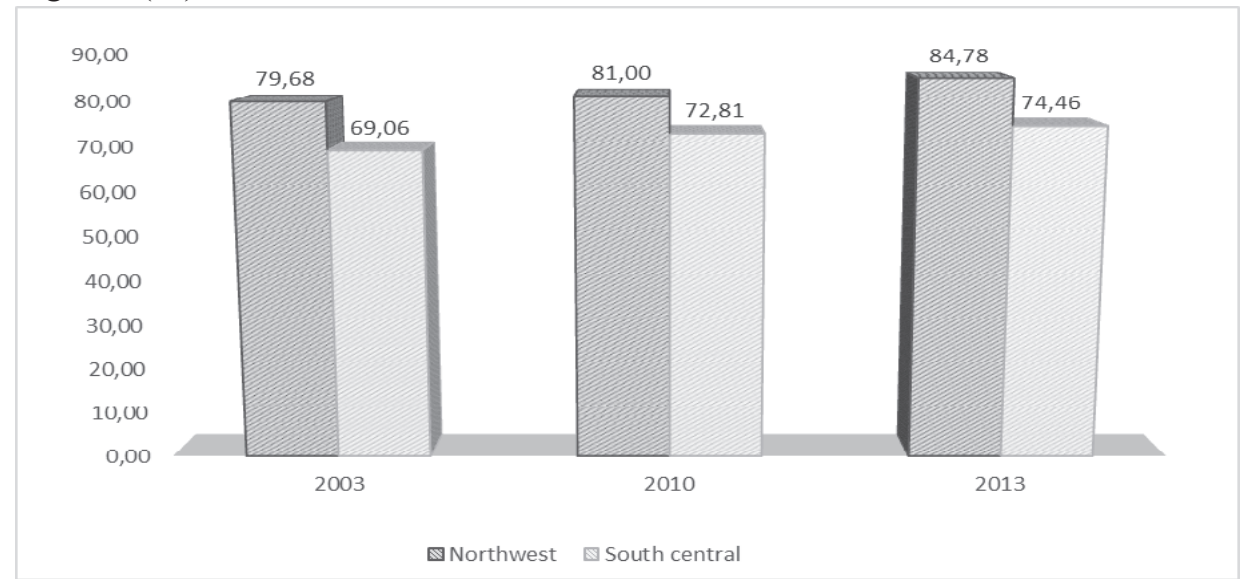

Source: National Statistical Institute, Agricultural land market and rent.

Differences are also observed with regard to the labour used. The share of family labour is $76 \%$ in the Northwest region versus $89.5 \%$ in the South Central region. Agricultural employment declined in the first region by almost $10 \%$, while in the South Central it grew by $13 \%$ in the ten-year survey period (Figure 9).

In the South Central Region, the opportunities for diversification of the economic activity towards the processing of agricultural products and other activities are used to a higher degree. Holdings by the other gainful activities carried out in the holding - South Central Region $-27 \%$ of all in the country versus only $8.1 \%$ in Northwest.

To a large extent, the different agricultural models have also affected the demographic processes in both regions. The population decreases in both regions, but while in the South Central it is about $8 \%$, it is $18.5 \%$ in the Northwest. At the rate of population decline, this is the fastest depopulating area in the last decade across the EU (Figure 10).

It can be summed up that in areas where the northern model agriculture exists:

- $\quad$ unemployment is risingł

- $\quad$ the population is aging;

- $\quad$ migration processes are higher; 
- the concentration of agricultural production is faster $(74.3 \%$ of the farms were destroyed in the last 10 years, while $61.6 \%$ in the Southern Central Region) and the average size of farms is growing;

- $\quad$ high degree of specialization of production on farms;

- the relative share of rented land increases;

- $\quad$ reduction in the use of labour and the family labour in agriculture.

Figure 9. Dynamics of the number of employed workers in agriculture in the Northwest and South Central regions (2006-2015)

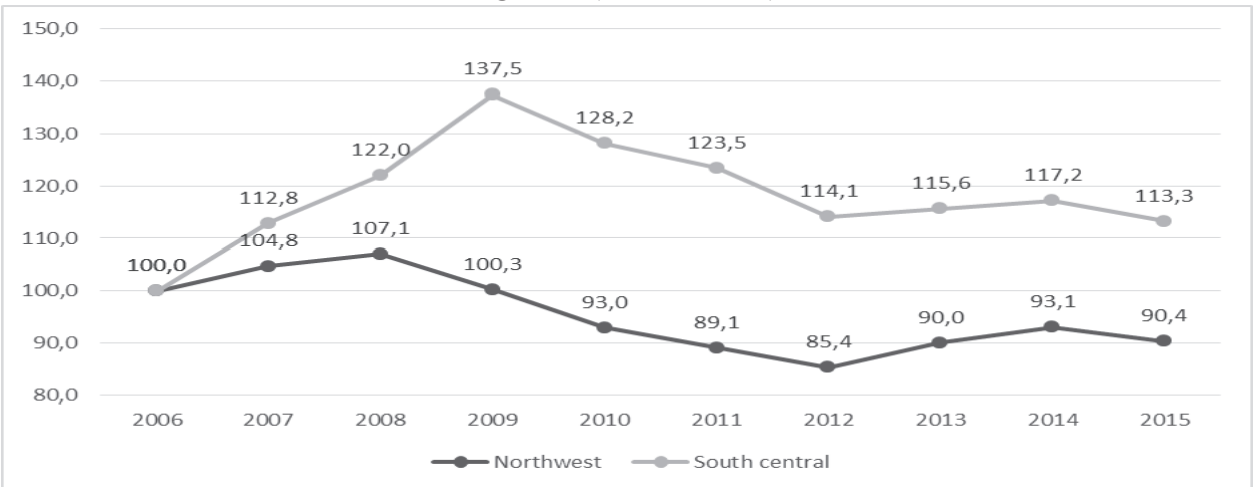

Source: own study based on NSI data for Employment.

Figure 10. Dynamics of population in Northwest and South Central regions for 2006-2016

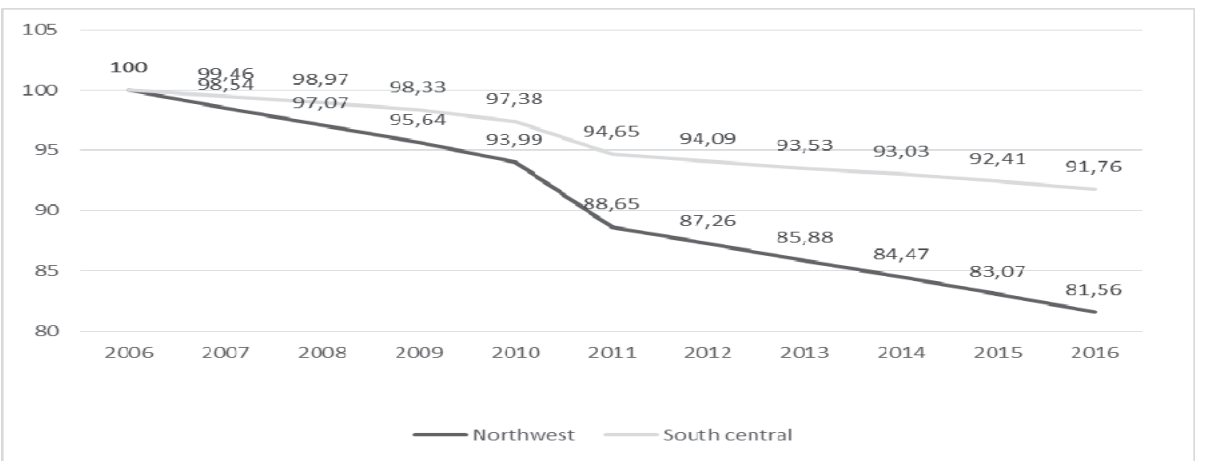

Source: own study based on NSI data for Population

Overall, this leads to higher business efficiency of farms, but at the cost of low income and population decline. In areas where the Southern model of agriculture is developing:

- Unemployment in rural areas is lower;

- Employment in agriculture is increasing;

- $\quad$ Family farms dominate, a large part of which is semi-marketable; 
- $\quad$ Farmers grow more and more diverse products creating higher added value;

- There is an increase in the number of farms that develop other activities that are the source of additional income.

Overall, in the South Central region a more diversified rural economy with higher entrepreneurship initiative is observed, as well as higher added value, including agricultural activities and tourism.

\subsection{Summary and conclusions}

In Bulgaria, both European agricultural models are developing together and successfully, as the effects for the development of the rural areas are well known and studied in other European countries. This creates opportunities for our country to implement foreign positive experience in developing the national agricultural policy and rural areas.

In areas with the predominance of narrowly specialized, large-scale farming, the focus should be on improving the market infrastructure. This might be possible when networks of producers are established, which will allow smaller producers to carry out effective economic activities. For this purpose more efforts must be put into adapting different measures of the national policy for stimulating the creation of networks of producers and improving the distribution and use of the direct payments. It is also necessary to take measures to reduce the adverse effects of specialized monoculture farming on the utilized agricultural area, water sources and other environmental aspects.

For the areas where the southern model of agriculture prevails, efforts for improvement and creation of new mechanisms to stimulate the development of family farms and the so-called vulnerable sectors should continue. Thus, expanding the production of fruit, vegetables and various livestock products will create the conditions for increasing the added value of the used resources and will increase the incomes of farmers.

Good practices from other countries, as well as Bulgarian traditions for cooperation between producers, demonstrate the need to create different forms of association and cooperation among farmers. This also may have an impact on the collective implementation of agri-environmental measures, which will contribute to a more effective and lasting provision of ecosystem services from farmlands. This in turn will influence in a positive manner the agri-environmental indicators for major aspects such as water, soil, atmosphere and biodiversity.

Last but not least, it is necessary to motivate local residents to use the "Community-led local development" approach in order to improve the market infrastructure for farmers in rural areas, as well as diversification of the economy and developing strategies for improvement of the quality of life of rural residents. 


\section{References}

1. Arnalte-Alegre, E., Ortiz-Miranda, D. (2013). The "Southern model" of European agriculture revisited: continuities and dynamics, in: Agriculture in Mediterranean Europe: between old and new paradigms, edited by D. Ortiz-Miranda, A. Moragues-Faus and E. Arnalte-Alegre, Emerald Group Publishing Limited, p.42.

2. Beopoulos, N., Damianakos, S. (1997). Gre' ce: Le cache-cache entre la moderniter et la tradition. In M. Jollivet (Ed.), Vers un rural postindustriel. Rural et environnement dans huit pays europe'enes (pp. 176-231). Paris: L'Harmattan.

3. Beopoulos, N. (2003). Mediterranean agriculture in the light and shadows of the CAP. In Ch. Kasimis \& G. Stathakis (Eds.), The reform of the CAP and rural development in Southern Europe (pp. 39-51). Aldershot: Ashgate.

4. European Commission, Directorate General for Agriculture (DG VI), Rural Developments, 1997.

5. Eurostat, Agri-environmental indicators, 2017.

6. Fabiani, G., Scarano, G. (1995). Una stratificazione socioeconomica delleaziende agrarie: pluralismo fuzionale e sviluppo territoriale. La Questione Agraria 59 , pp. $27-91$.

7. Feindt, P.H. (2008). Sozial-ökologische entwicklungsprobleme von landwirtschaft und agrarpolitik: eine annäherung, in: P.H. Feindt, M. Gottschick, T. Mölders, F. Müller, R. Sodtke and S. Weiland (eds) Nachhaltige Agrarpolitik als reflexive Politik: Plädoyer für einen neuen Diskurs zwischen Politik und Wissenschaft. Berlin: edition sigma, pp. 25-40.

8. Ilbery, B., Maye, D. (2010). Agricultural restructuring and changing food networks in the UK. In N.M.Coe and A.Jones (Eds.), Reading the economy\& The EK in the 21st century, London:Sage, pp.166-180.

9. Lowe, P., Murdoch, J., Marsden T., Munton, R., Flynn, A. (1993). Regulating the new rural spaces: The uneven development of land. Journal of rural studies, 9(3), pp. 205-222.

10. Ministry of Agriculture, Foods and Forestry, Agrostatistics.

11. Ministry of Agriculture, Foods and Forestry, Rural development programme 2007-2013, 2007, 2014.

12. Ministry of Agriculture, Foods and Forestry, Assessment of the Rural Development Programme 2014-2020, 2014.

13. National Statistical Institute, http://www.nsi.bg/en/content.

14.Zegar J. (2012). The competitiveness of sustainable agriculture. An outline of research problems, in J. Zegar, Z. Florianczyk, M. Kwasek, W. Wrzaczcz From the research on socially-sustainable agriculture, Institute of agricultural and food economics - National research institute, Warsaw, pp.11-40. 